\title{
Regulation of protein synthesis in rat liver cell-free systems by amino acids
}

\author{
By M. J. Clemens (Beit Memorial Fellow), National Institutefor Medical Research, \\ Mill Hill, London $\mathrm{NW}_{7}$ г $A A$
}

Changes in the availability of amino acids affect polysome formation and the rate of protein synthesis in several tissues. This has been shown for rat and mouse liver by in vivo force-feeding experiments (Wunner, Bell \& Munro, 1966; Sidransky, Sarma, Bongiorno \& Verney, 1968 ), in a perfusion system (Jefferson \& Korner, 1969) and in a cell-free preparation (Baliga, Pronczuk \& Munro, r968). In addition to these acute effects, long-term starvation followed by refeeding produces analogous responses (Sox \& Hoagland, I966; Webb, Blobel \& Potter, ı966; Wilson \& Hoagland, 1967). It has been assumed by many workers that the extent of polysome aggregation determines the rate of protein synthesis within the cell and may be taken as a measure of this. There is an increasing body of evidence to suggest, however, that the activity of other components of the protein synthetic machinery can be influenced by a variety of environmental factors, including nutritional ones.

\section{Cell-free systems from incubated liver slices}

Post-mitochondrial supernatants can be prepared from homogenates of rat liver slices which have been incubated for $\mathrm{I} h$ in a medium containing either normal plasma concentrations of twenty amino acids or six times these concentrations. Under the appropriate conditions these supernatants will incorporate radioactive amino acids into protein and it can be shown that the extract obtained from the tissue exposed to the higher amino acid levels is more active in this respect (Clemens $\&$ Korner, 197I). The increased activity is due to increased ability of the cell-sap (high speed supernatant) fraction to support amino acid incorporation, and no change in the ribosomes themselves is seen. This effect of amino acids appears to be distinct from the stimulation of polysome formation reported with other experimental systems.

Further details concerning the nature of the stimulation of cell-sap activity have now been obtained. The effect is seen with either free amino acids or added aminoacyl-tRNA as radioactive precursor in the post-mitochondrial supernatant system (Table I) and excess added tRNA does not abolish it (Table 2). Supplementation of the cell-free system with extra amino acids (above the usual concentration of $20 \mu \mathrm{mol} / 1 \mathrm{each}$ ) does not stimulate incorporation or affect the difference in activity between extracts from incubations of liver slices containing high or low 
Table I. Effect of high amino acid concentrations in liver-slice incubation medium on subsequent ability of pastmitochondrial supernatants to incorporate radioactivity into protein from a variety of precursors

\begin{tabular}{|c|c|c|}
\hline $\begin{array}{c}\text { Amino acid } \\
\text { concentration in } \\
\text { incubation medium } \\
(\times \text { serum level })\end{array}$ & $\begin{array}{c}\text { Precursor } \\
\text { in cell-free system }\end{array}$ & $\begin{array}{l}\text { Incorporation into } \\
\text { protein } \\
\text { (counts/min per } \mu \mathrm{g} \\
\text { rRNA) }\end{array}$ \\
\hline I & {$\left[{ }^{14} \mathrm{C}\right]$ phenylalanine } & 127 \\
\hline 6 & {$\left[{ }^{14} \mathrm{C}\right]$ phenylalanine } & 234 \\
\hline I & $\begin{array}{l}{ }^{14} \mathrm{C} \text {-labelled seryl- } \\
\text { tRNA }\end{array}$ & $5 \cdot 26$ \\
\hline 6 & $\begin{array}{l}{ }^{14} \text { C-labelled seryl- } \\
\text { tRNA }\end{array}$ & 10.44 \\
\hline I & $\begin{array}{l}{ }^{14} \mathrm{C} \text {-labelled } \\
\text { aminoacyl-tRNA }\end{array}$ & $9 \cdot 01$ \\
\hline 6 & $\begin{array}{l}{ }^{14} \mathrm{C} \text {-labelled } \\
\text { aminoacyl-tRNA }\end{array}$ & 1549 \\
\hline
\end{tabular}

Table 2. Effect of addition of tRNA to postmitochondrial supernatant cell-free systems prepared from liver slices incubated in two concentrations of amino acids

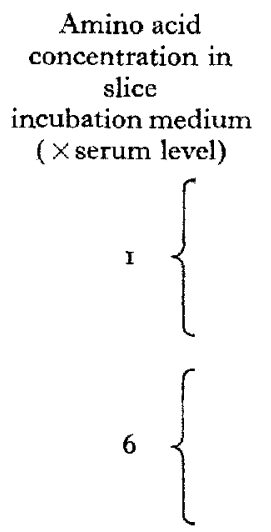

$\begin{array}{cc}\text { Amount of tRNA } & \begin{array}{c}\text { Incorporation of } \\ \text { [14 C]phenylalanine } \\ \text { into protein } \\ (\mu \mathrm{g} / 0.1 \mathrm{ml})\end{array} \\ 0 & \begin{array}{c}{ }^{4} \text { (counts/min per } \mu \mathrm{g} \\ \text { rRNA) }\end{array} \\ 5 & 55.7 \\ 10 & 80.1 \\ 20 & 87.5 \\ 30 & 94.6 \\ & 100.8 \\ 0 & 79.3 \\ 5 & 118.0 \\ 10 & 127.0 \\ 20 & 135.8 \\ 30 & 135.6\end{array}$

concentrations of amino acids. It is therefore unlikely that either increased amino acid activation or increased supply of a type of rate-limiting aminoacyl-tRNA can account for the raised activity. As shown in Fig. I, cell sap from liver slices incubated with high concentrations of amino acids is also more active in supporting the polyuridylic acid (poly U)-directed synthesis of polyphenylalanine by preincubated, salt-washed ribosomes over a range of $\mathrm{Mg}^{2+}$ concentrations. However, ribosome attachment to $\mathrm{mRNA}$ and in vitro peptide-chain initiation are not prerequisites for expression of the increased sap activity in systems where endogenous mRNAdirected protein synthesis is assayed (as in the postmitochondrial supernatants or when non-preincubated ribosomes are used). This is concluded from the failure of sodium fluoride and other inhibitors of in vitro chain initiation to abolish the effect (Fig. 2). 


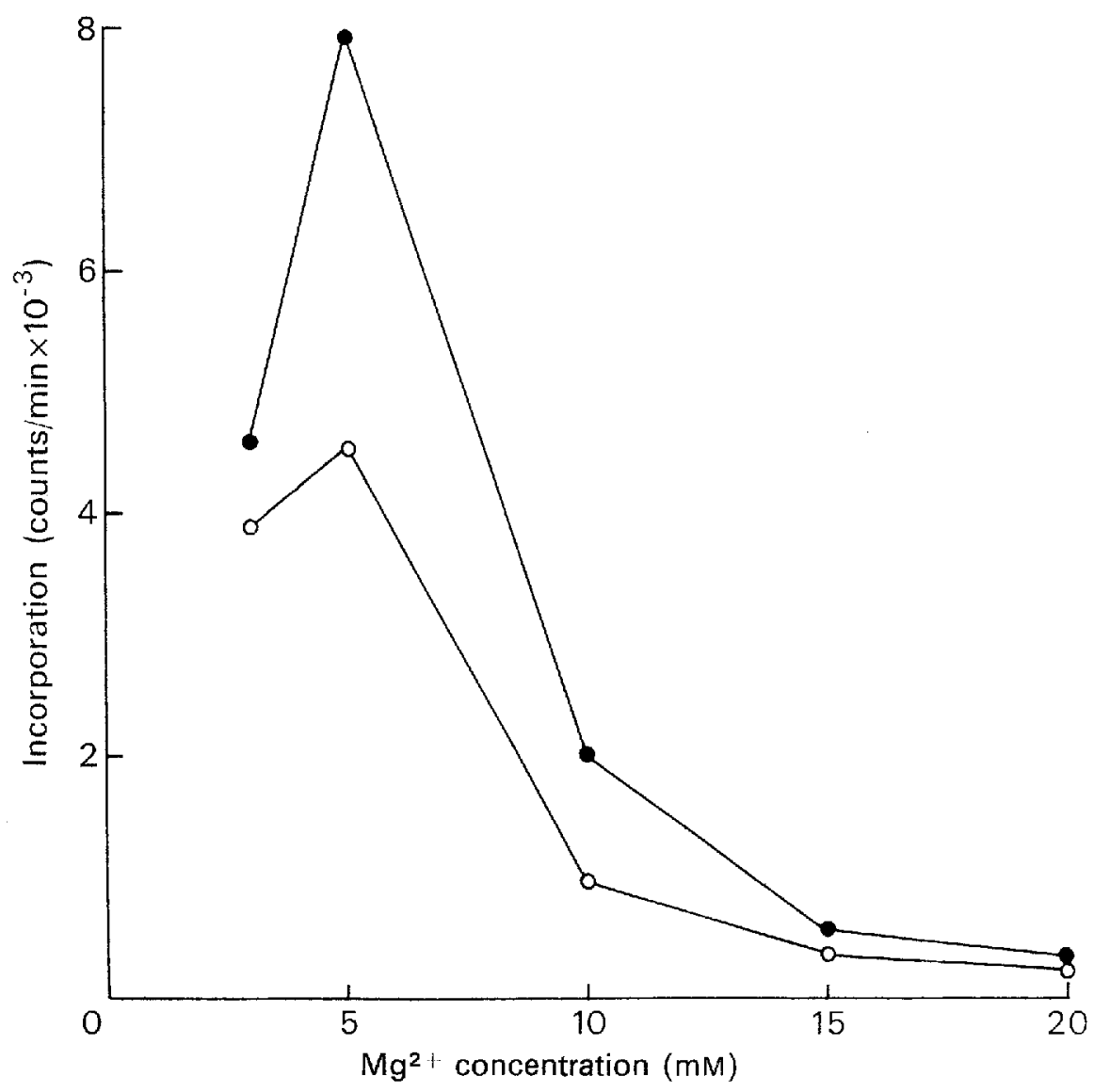

Fig. I. Amino acid effect on ability of cell sap to support poly U-directed phenylalanine incorporation during a $40 \mathrm{~min}$ incubation with preincubated, salt-washed ribosomes. $O$, cell sap from liver slices incubated in normal serum concentrations of amino acids;, cell sap from liver slices incubated in six times serum concentrations of amino acids.

Time-courses of amino acid incorporation in vitro indicate that the increased cell-sap activity results in both a greater initial rate and a greater final amount of polypeptide synthesis per unit of ribosomes. Since initiation has been excluded as a cause for this effect, activation of ribosomes already attached to mRNA is a more likely explanation (see below). The results do not at present distinguish between a higher rate of peptide-chain elongation on each ribosome or an increased proportion of ribosomes actively translating mRNA at the same rate as in the control system.

Regulation of cell-sap activity in other systems

The possibility of modulation of ribosome activity in rat liver by factors in the soluble fraction of the cell has been raised by several workers. Decken (1969) fractionated rat liver-cell sap into stimulatory and inhibitory components for protein synthesis and found that the activity of the former increased, and the latter decreased, after a protein meal. Similarly, Wannemacher, Wannemacher \& Yatvin (I97I) 


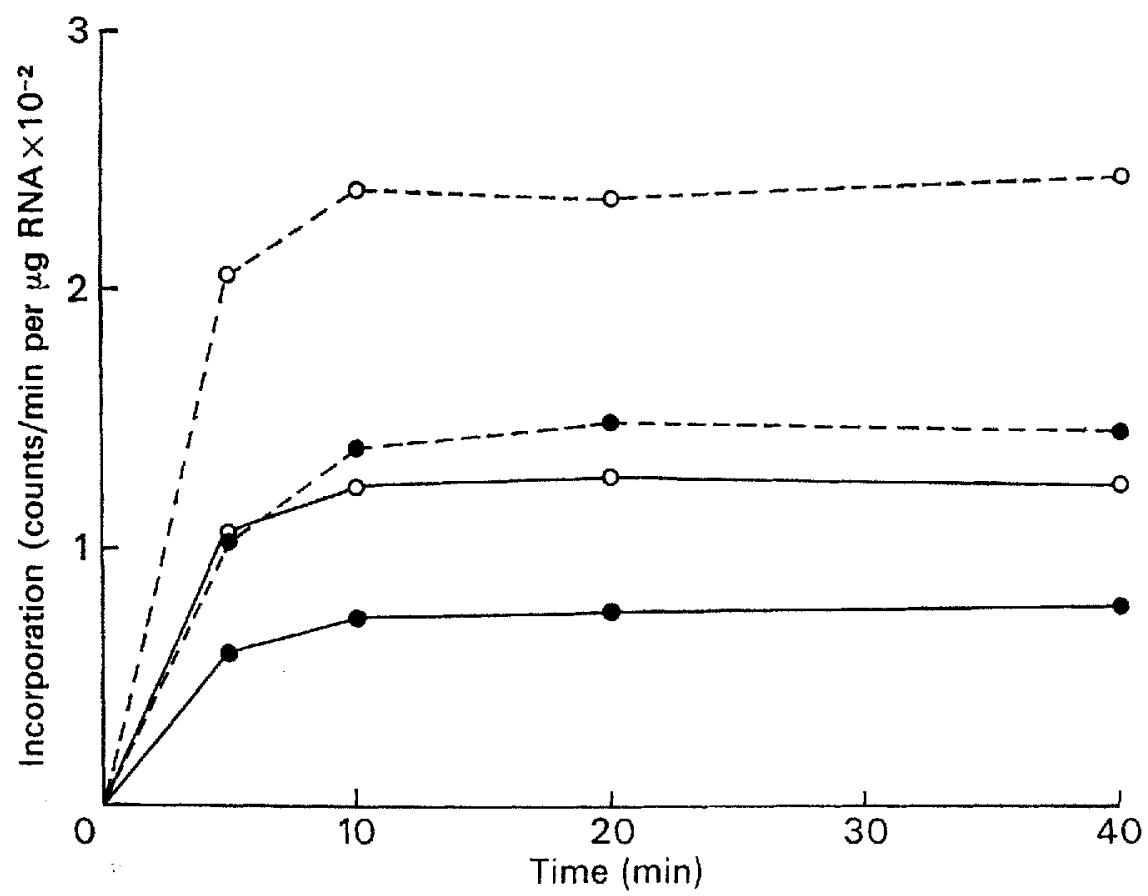

Fig. 2. Amino acid effect on protein synthetic activity of postmitochondrial supernatants in the absence of in vitro chain initiation. $O$, incubations without sodium fluoride; 9 , incubations with ro $\mathrm{mm} \mathrm{NaF}$; (-), cell-free system from liver slices incubated in normal serum concentrations of amino acids; (- - - ), cell-free system from liver slices incubated in six times serum concentrations of amino acids.

reported that liver ribosomal activity was lower in rats given a low-protein diet compared to controls receiving an adequate diet. These changes in activity were correlated with changes in intracellular amino acid concentrations and it was suggested that the release or synthesis of 'translation factors' could effect these modulations of ribosome activity. The variations of liver protein synthetic rates between individual fed rats appear to be entirely due to changes in polysome activity (rather than size), which Henshaw, Hirsch, Morton \& Hiatt (1971) again attributed to changes in soluble factors rather than the ribosomes themselves.

Liver is not the only tissue which shows changes in ability of cell sap to support protein synthesis. Starvation also diminishes the activity of muscle sap in a cellfree system (Migliorini \& Manchester, 1971). Ascites cells in culture respond to improved nutritional conditions (glucose plus essential amino acids) by a threefold increase in the rate of protein synthesis per cell, which is partly attributable to a greater rate of peptide-chain elongation per unit of polysomal RNA (Venrooij, Henshaw \& Hirsch, 1970).

In Streptococcus faecalis, valine starvation has been reported to reduce the ability of the supernatant to catalyse poly U-directed protein synthesis with Escherichia coli ribosomes (Daneo-Moore \& Shockman, 1969). The activity of $\mathrm{pH} 5$ enzymes from nephrotic rat kidney is greater compared with control preparations (Nicholls, Ryan, Miall, Westall \& Cappon, 1970), and hormones controlling 


\section{Vol. 3I Amino acid supply and polynucleotide and protein metabolism 277}

growth and protein synthesis may also have effects at this level (M. J. Clemens, unpublished observations). Thus the phenomena considered here, for which the response of liver slices to amino acids may constitute an experimentally convenient system, may well be of general occurrence and importance.

\section{The relationship of polysomes to protein synthesis}

It is generally recognized that polyribosomes are the functional sites of protein synthesis in the cell but the quantitative relationship between the rate of protein synthesis and the proportion of ribosomes in polysomes may be a complex one. Clearly, the latter represents a balance between the rates of initiation, ribosome movement along the mRNA and ribosome release from mRNA (Gordon, 1969; Vassart, Dumont \& Cantraine, I971), and in many instances a conversion of monomeric ribosomes into polysomes accompanies increased rates of protein synthesis and growth. This is presumably due to increased initiation relative to the other steps in protein synthesis and is a well-documented effect of a plentiful supply of amino acids (Wunner et al. 1966; Sidransky et al. 1968; Jefferson \& Korner, 1969; Vaughan, Pawlowski \& Forchhammer, 1971). Decreased chain initiation may not be solely responsible for polysome breakdown during amino acid starvation, however, since Brunschede \& Bremer (I971) have shown that amino acid deprivation in $E$. coli leads to premature termination of peptide chains with release of ribosomes from the mRNA at points where addition of the deficient amino acid is unable to occur. Conversely, the behaviour of reticulocytes incubated in amino acid-limiting media actually produces an increase in polysomes, due to a slower rate of translation relative to initiation (Knopf \& Lamfrom, 1965). In addition, the possibility exists that not all ribosomes in polysomes are active in chain elongation (Hunter \& Korner, 1969). The inactive ribosomes could restrict the movement along the polysome of active ribosomes. This model has been invoked by Scornik ( 1969 ) to explain the difference in protein synthetic activity between ribosomes from normal or regenerating liver.

These considerations, taken together, emphasize the need for caution in the interpretation of polysome profiles on sucrose gradients, particularly if these are obtained without parallel studies on rates of protein synthesis both in vitro and in vivo. However, the likelihood of an increased rate or extent of peptide-chain elongation under conditions of plentiful amino acid supply is not incompatible with increased polysome formation if either chain initiation is increased even more than elongation or ribosomes stand less chance of prematurely detaching from mRNA under these circumstances.

\section{The relationship of amino acids to the mechanism of action of growth hormone}

Jefferson \& Korner (1967) and Clemens \& Korner (1970) have shown that growth hormone stimulates directly the labelling of protein and RNA in perfused liver or liver slices from normal rats, but only when amino acids are present in the medium at three or six times plasma levels. These results suggest that the protein synthetic ability of the liver may be limited unless amino acids are in plentiful supply. Although 
growth hormone, like amino acids, stimulates polysome formation and protein synthesis (Korner, I964), the two agents probably act by different mechanisms. This is suggested by the results of amino acid force-feeding experiments with hypophysectomized rats and those treated with growth hormone (V. M. Pain and M. J. Clemens, unpublished work).

\section{Mechanism of action of amino acids on liver cell-sap activity}

The precise mechanism whereby increased amino acid supply can improve the capacity of rat liver cell-sap to support amino acid incorporation is not known. Greater activity of either of the soluble factors transferase I (aminoacyl-tRNA binding enzyme) or transferase II (translocation factor) may be one explanation. It is known that the activity of transferase $I$ in vitro is very sensitive to conditions of incubation. It undergoes rapid inactivation at $37^{\circ}$ unless stabilized by the presence of aminoacyl-tRNA (Ibuki, Gąsior \& Moldave, I966) but tRNA not charged with amino acids does not protect against inactivation. It is conceivable that such a mechanism operates within the cell. Amino acids could control transferase I activity by means of the level of charging of tRNA.

An alternative possibility has been raised by the recent findings of Dice \& Schimke (1972). They demonstrated that exchange of ribosomal proteins between the ribosomes and the supernatant fraction can occur. It is conceivable that the protein synthetic activity of ribosomes could be controlled by the source of supernatant through such an exchange process.

In addition to effects on cellular protein synthesis, amino acids can control protein degradation (Munro, r968; Hershko \& Tomkins, 1971) and such an effect could provide an explanation for the results of the experiments with liver slices reported here. The rate of degradation of specific proteins controlling the rate of total protein synthesis may be reduced in the presence of high concentrations of amino acids. However, until the nature of the factors responsible for the amino acid activation of the protein synthetic ability of cell sap has been established it will not be possible to distinguish between increased activity and increased tissue content (per mg of liver protein) of these factors.

\section{The physiological significance of amino acid effects}

The protein-synthetic activity of cell-free systems prepared from liver slices responds very rapidly to increased amino acid supply (Hanking \& Roberts, 1965; Clemens \& Korner, 1971). In vivo, such rapid effects (together with similarly rapid recruitment of ribosomes into polysomes) could constitute a mechanism whereby the liver responds to ingestion of a protein meal by increasing its protein synthetic rate when presented with amino acids through the portal vein (see Munro, 1968).

Longer-term variations in protein synthetic rate (which for liver and muscle correlates with rate of body growth; Henshaw et al. 197x) may also be related to variations in cell-sap activity. It is possible that amino acid supply may have a role to play in these chronic changes also. 


\section{REFERENCES}

Baliga, B. S., Pronczuk, A. W. \& Munro, H. N. (r 968). F. molec. Biol. 34, r99.

Brunschede, H. \& Bremer, H. (1971). F. molec. Biol. 57, 35 .

Clemens, M. J. \& Korner, A. (1970). Biochem. F. II9, 629.

Clemens, M. J. \& Kotner, A. (197I). Nature, New Biology 232, 252.

Daneo-Moore, L. \& Shockman, G. D. (I969). Biochim. biophys. Acta I95, 145.

Decken, A. von der (1969). Expl Cell Res. 56, 309.

Dice, J. F. \& Schimke, R. T. (1972). F. biol. Chem. 247, 98.

Gordon, R. (1969). F. theor. Biol. 22, 5 I5.

Hanking, B. M. \& Roberts, S. (1965). Nature, Lond. 207, 862.

Henshaw, E. C., Hirsch, C. A., Morton, B. E. \& Hiatt, H. H. (1971). F. biol. Chem. 246, 436 .

Hershko, A. \& Tomkins, G. M. (1971). F. biol. Chem. 246, 7 10.

Hunter, A. R. \& Korner, A. (1969). Biochim. biophys. Acta r79, I 5.

Ibuki, F., Gąsior, E. \& Moldave, K. (1966). F. biol. Chem. 24x, 2188.

Jefferson, L. S. \& Korner, A. (1967). Biochem. F. 104, 826.

Jefferson, L. S. \& Korner, A. (r969). Biochem. F. Irr, 703.

Knopf, P. M. \& Lamfrom, H. (1965). Biochim. biophys. Acta 95, 398.

Korner, A. (1964). Biochem. $\mathscr{~ 9 2 , ~} 449$.

Migliorini, R. H. \& Manchester, K. L. (1971). FEBS Lett. x3, 140.

Munro, H. N. (1968). Fedn Proc. Fedn Am. Socs exp. Biol. 27, 123 I.

Nicholls, D. M., Ryan, M. P., Miall, S. H., Westall, C. G. \& Cappon, I. D. (1970). Can. F. Biochem. 48,308 .

Scornik, O. A. (1969). Proc. natn. Acad. Sci. U.S.A. 64, 143 r.

Sidransky, H., Sarma, D. S. R., Bongiorno, M. \& Verney, E. (I968). F. biol. Chem. 243, I 23.

Sox, H. C. Jr \& Hoagland, M. B. (1966). \%. molec. Biol. 20, Ir 3 .

Vassart, G., Dumont, J. E. \& Cantraine, F. R. L. (1971). Biochim. biophys. Acta 247, 471.

Vaughan, M. H. Jr, Pawlowski, P. J. \& Forchhammer, J. (1971). Proc. Nat. Acad. Sci. U.S.A. 68, 2057 .

Venrooij, W. J. W. van, Henshaw, E. C. \& Hirsch, C. A. (1970). F. biol. Chem. $245,5947$.

Wannemacher, R. W. Jr, Wannemacher, C. F. \& Yatvin, M. B. (197I). Biochem. F. 124, 385.

Webb, T. E., Blobel, G. \& Potter, V. R. (1966). Cancer Res. 26, 253.

Wilson, S. H. \& Hoagland, M. B. (1967). Biochem. F. 103, 556 .

Wunner, W. H., Bell, J. \& Munro, H. N. (1966). Biochem. F. 101, 4I7. 